\title{
Evaluation of environmental bacterial contamination and procedures to control cross infection in a sample of Italian dental surgeries
}

Silvano Monarca, Mario Grottolo, Daniela Renzi, Corrado Paganelli, Pierluigi Sapelli, Ilaria Zerbini, Giuseppe Nardi

\begin{abstract}
Objectives-To perform a pilot study on bacterial contamination in some dental surgeries $(n=51)$ in a local health unit in Brescia (Lombardy Region, Italy) and to evaluate the procedures to control cross infection used by the personnel to reduce the risk of infection in dental practice. Methods-A survey was carried out by interviewing 133 dental personnel with a questionnaire on the procedures used to control infection. The autoclaves, chemical baths (chemiclaves), and ovens present in the surgeries were tested for sterilisation efficiency with a spore test, and already packed and sterilised instruments were randomly sampled and tested for sterility. Microbial contamination of air, surface, and dental unit water samples were also studied.

Results-The dental personnel did not generally follow the principal procedures for infection control: $30 \%$ of personnel were not vaccinated against hepatitis $B$ virus, infected instruments were often not decontaminated, periodic checks of autoclave efficiency were lacking, and the knowledge of disinfection mechanisms and procedures was incomplete. High bacteriological contamination of water at dental surgeries was often found and total bacteriological counts in air samples were high. Surface studies showed widespread bacterial contamination.

Conclusions-On the basis of these results, an educational programme for the prevention of infective hazards has been prepared and carried out. The results of this pilot study will be used for planning a national survey.

(Occup Environ Med 2000;57:721-726)
\end{abstract}

Keywords: dental surgeries; bacterial contamination; cross infection control procedures

Research has shown that infective hazards are present in dental practice, because many infections can be transmitted by blood or saliva through direct or indirect contact, droplets, aerosols, or contaminated instruments and equipment. ${ }^{1}$ All dental personnel are at risk, including dentists, nurses, and hygienists, who may transmit infectious diseases to patients by the use of contaminated dental instruments or hands. This microbial cross contamination is particularly dangerous when considering immunodeficient patients.

Previous seroepidemiological studies have confirmed these occupational hazards, showing higher concentrations of serum antigen and antibodies for hepatitis $\mathrm{B},{ }^{1-3}$ hepatitis $\mathrm{C},{ }^{45}$ and Legionella spp, ${ }^{6}$ in dentists than in the lay population and an increased prevalence of respiratory infections $s^{7}$ and symptoms ${ }^{8}$ possibly related to aerosols. The potential for transmission of disease and cross contamination at the chairside is obvious, yet any item contaminated by a patient's saliva or blood is a potential source of cross contamination and transmission of disease. In the United States the Occupational Safety and Health Administration's standard for occupational exposure to blood borne pathogens considers items that have been contaminated by saliva in dental procedures and have not been decontaminated as potentially infectious, ${ }^{9}{ }^{10}$ and it is known that many infectious agents, if present in high numbers, can survive for several days when associated with body fluids containing protein. Therefore, practices to control infection should be a part of the organisation of every dental surgery.

Although it is well known that air, surfaces, dental materials and instruments, and water in dental units could be vehicles for cross contamination with various microorganisms, information on the microbial contamination of the dental surgery environment is still lacking.

Some researchers have studied the bacterial contamination of air samples collected in dental surgeries. ${ }^{11-13}$ Infectious aerosols may be generated during dental practice, especially when high speed handpieces or ultrasonic scalers are used without a high volume evacuator, ${ }^{14}$ and there are data that support the potential transmission of infectious diseases through inhalation of these aerosols. The potential air contamination of dental surgeries by infectious aerosols has also been pointed out by the Centers for Disease Control and Prevention in Atlanta, which recommend that all sources of blood contaminated splatter and aerosols be minimised with rubber dams, high velocity evacuation, and proper positioning of the patient. $^{15}$

Previous studies have shown extensive contamination of water in dental units, not only with water saprophytes, but also with some potentially pathogenic microorganisms such as Legionella pneumophila, ${ }^{16}$ and Pseudomonas aeruginosa. ${ }^{17}{ }^{18}$ Bacterial counts as high as tens 
of millions of colony forming units $/ \mathrm{ml}$ ( $\mathrm{cfu} / \mathrm{ml}$ ) have been reported. These counts far exceed the $200 \mathrm{cfu} / \mathrm{ml}$ goal for aerobic mesophilic bacteria suggested by the American Dental Association for dental surgery. ${ }^{19}$ Biofilm formation along the walls of the fine bore waterlines seems to be the primary factor responsible for dental unit waterline contamination. ${ }^{19}{ }^{20}$ The health hazards for patients posed by high levels of bacteria in dental unit waterlines is still unresolved. However, some cases of infections in immunocompromised patients have been reported. ${ }^{21}$

Data on microbial contamination of surfaces or instruments in dental surgeries are scarce. Some research has shown extensive contamination of surfaces and instruments in dental surgeries by hepatitis $\mathrm{B}$ surface antigen, ${ }^{22}$ and hepatitis $\mathrm{C}$ virus (HCV), ${ }^{23}$ but current publications do not contain any data on bacterial contamination.

Concerns about control of infection in dentistry have been heightened by a report of transmission of human immunodeficiency virus (HIV) from an American dentist to five of his patients. ${ }^{24}{ }^{25}$ The use of procedures to control infection and universal precautions in the dental surgery is effective in preventing microbial pollution and cross contamination and is strongly supported by organisations such as the Centers for Disease Control and Prevention, the American Dental Association, schools of dentistry, and many other health agencies and professional associations. ${ }^{15}$ For this reason, since the end of the 1980s many surveys have been carried out in several countries, especially in North America and Europe, to investigate practices to control infection and compliance with universal precautions in dental surgeries. ${ }^{26-32}$ More recent surveys have shown improved compliance with recommended practices to control infection over time. ${ }^{334}$ In many cases, however, the results showed the need for further educational efforts to promote universal precautions and a high standard of hygiene in dental practice.

There is no current research studying the microbial contamination of air, water, and surfaces in dental surgeries concurrently with the procedures to control infection followed by dental personnel.

The aim of this study was threefold: firstly to assess the knowledge, attitudes, and behaviour of dentists of a local health unit in Lombardy, Northern Italy, in techniques to control cross infection; secondly to study microbial contamination of the air, surfaces, materials, and water in these dental surgeries; and thirdly to set up an educational programme based on the results obtained to improve the adoption of infection control techniques. This is a pilot study for a future larger Italian survey on infective hazards in dental practice.

\section{Materials and methods}

DENTAL SURGERIES AND PERSONNEL

Lombardy is one of the most highly industrialised regions in Italy. All the self employed dentists $(n=62)$ in a local health unit in Lombardy and 71 nurses working in 51 private dental surgeries were involved in this comprehensive programme organised with the assistance of university researchers from the Dental Clinic and Chair of Hygiene at the University of Brescia, and health officers from the local health unit. The aim was to evaluate with a questionnaire the procedures used by the personnel to control infection, to study microbiological contamination in dental surgeries, and to test autoclaves for efficiency of sterilisation. The main targets of the research were the owners of the dental surgeries, as they are responsible for the health and safety of employed dental personnel, according to the Italian law (No 626, 1994) and some European Union (EU) directives (89/391/EU, 89/654/ EU, 89/656/EU, 90/679/EU). Unlike the American Dental Association, the Italian Dental Association has not produced guidelines for procedures to control infection.

The results obtained were used to set up an educational programme for improving compliance with procedures to control infection by the dental personnel involved in the research.

QUESTIONNAIRE

A self administered questionnaire was given to all the personnel in the dental surgeries to analyse the following data: (a) personal details (age, duration of occupation, etc); (b) structure of the dental surgery (total surface area, number of rooms, number of operating rooms, type of floor, presence of dental technician laboratory, number of dental units, autoclaves, chemical baths (chemiclaves), and ovens present, etc); (c) instruments, materials, and techniques used for the prevention of infective hazards for both personnel and patients (protective systems, use of disposable items, disinfection and sterilisation procedures, handling of contaminated materials, etc); (d) episodes of infection and vaccination against hepatitis $B$, and other vaccines used.

\section{BACTERIAL CONTAMINATION OF AIR}

Contamination of air was tested in the 51 surgeries with an air sampler (SAS, Surface Air System, PBI International, Milan, Italy) and different agar plates (Rodac, Becton Dickinson, Cockeyville, MD) placed near the assistant, about $1.5 \mathrm{~m}$ from the patient, to calculate total counts of bacteria, fungi, Staphylococci, and Streptococci. Each sampling lasted for 2 minutes at a flow rate of $1801 / \mathrm{min}$ and collected 3601 of air. The data were expressed as $\mathrm{cfu} / \mathrm{m}^{3}$.

All the bacteriological analyses were carried out by technicians at the Microbiological Laboratory of the Local Health Unit of Brescia.

BACTERIAL CONTAMINATION OF SURFACES Contamination of surfaces was tested with contact plates (Rodac, $55 \mathrm{~mm}$ diameter, 24 $\mathrm{cm}^{2}$ area) pressed on one trolley per surgery placed near the dental unit, to analyze total bacterial counts, fungi, Staphylococci, and $\beta$-haemolytic Streptococci. The data were expressed as $\mathrm{cfu} / 24 \mathrm{~cm}^{2}$. 
BACTERIAL CONTAMINATION OF WATER IN DENTAL UNITS

Water distributed in the 51 dental units was sampled at the hose and air-water syringe (two samples/surgery) and investigated for several microbial variables (total bacterial counts at $22^{\circ} \mathrm{C}$ and $37^{\circ} \mathrm{C}$, total coliforms, fecal coliforms, fecal Streptococci, sulphite reducing Clostridia, coliphages, Staphylococci, Legionella species, and Pseudomonas species). ${ }^{35}$

Total bacterial counts at $22^{\circ} \mathrm{C}$ and $37^{\circ} \mathrm{C}$ were expressed as $\mathrm{cfu} / \mathrm{ml}$ and compared with the American Dental Association goal $(<200$ $\mathrm{cfu} / \mathrm{ml}),{ }^{19}$ and with EU drinking water guidelines $\left(<10 \mathrm{cfu} / \mathrm{ml}\right.$ at $37^{\circ} \mathrm{C}$ and $<100 \mathrm{cfu} / \mathrm{ml}$ at $\left.22^{\circ} \mathrm{C}\right) . .^{36}$

SPORE TEST FOR AUTOCLAVES, CHEMICLAVES, AND OVENS

The autoclaves, chemiclaves (operating with formaldehyde and organic solvents), and ovens (with door operated manually) present in the dental surgeries were of different types and only a few had cycle recorders.

These devices were tested for sterilisation efficiency with the spore test (strips containing Bacillus stearothermophylus and Bacillus subtilis spores). One strip was placed in the same steriliser packaging used at the practice and then in the centre of a normal load. A second strip was set aside to be used as a positive control. After the standard operating procedure for sterilisation, the spore strips were aseptically transferred to tubes containing trypticase soy broth and incubated for 7 days at $37^{\circ} \mathrm{C}$ (for dry heat sterilisation) or at $55^{\circ} \mathrm{C}$ (for steam or chemiclave sterilisation).

STERILITY TESTS FOR STERILIZED INSTRUMENTS One sterilised and packed endodontic instrument per surgery was randomly sampled and analysed for sterility by opening the packaging aseptically, immersing the instrument in broth and incubating it for 48 hours at $37^{\circ} \mathrm{C}$. It was then stored at room temperature in a closed cupboard.

\section{Results}

QUESTIONNAIRE

Reported hepatitis $B$ infection and vaccination

Of the dentists $67.7 \%$ and of the nurses $71.8 \%$ said they had received a hepatitis $B$ vaccination (table 1). Eight dentists (12.9\%) and four nurses $(5.6 \%)$ reported that they had had hepatitis $B$ in the past.

\section{Protective procedures}

About $95 \%$ of personnel claimed to use masks, gloves, and a high speed vacuum, whereas glasses $(90.9 \%)$ and shields $(70.7 \%)$ were less often used (table 1). Disposable materials were widely used, although only $67.7 \%$ used disposable white coats for high risk patients and $29.3 \%$ disposable burs. Critical points of dental units were not often covered with polyethylene film $(44.4 \%)$.

\section{Decontamination procedures}

Correct procedures for the decontamination of contaminated instruments before sterilisation
Table 1 Infection control procedures reported by dental personnel (62 dentists and 71 nurses) at 51 dental surgeries in a local health unit in Lombardy

\begin{tabular}{lrl}
\hline Protective measures adopted & $n$ & $\%$ \\
\hline Anti-HBV vaccination rate & & \\
$\quad$ Dentists & 42 & 67.7 \\
$\quad$ Nurses & 51 & 71.8 \\
Masks & 126 & 94.7 \\
Gloves & 126 & 94.7 \\
Glasses & 121 & 90.9 \\
Shields & 94 & 70.7 \\
Covering with polyethylene film & 59 & 44.4 \\
Disposable gowns $\dagger$ & 90 & 67.7 \\
Disposable burs & 39 & 29.3 \\
High speed vacuum & 126 & 94.7 \\
Decontamination of instruments & 85 & 63.9 \\
\hline
\end{tabular}

${ }^{\star}$ Eight dentists $(12.9 \%)$ and four nurses $(5.6 \%)$ reported having had hepatitis B in the past.

tOnly for high risk patients.

Table 2 Reported presence and use of sterilisation devices and results of spore and sterility tests in 51 dental surgeries in a local health unit in Lombardy

\begin{tabular}{|c|c|c|}
\hline & $n$ & $\%$ \\
\hline \multicolumn{3}{|l|}{ Sterilisation devices: } \\
\hline Autoclaves & 35 & 68.6 \\
\hline Chemiclaves & 7 & 13.7 \\
\hline Ovens & 6 & 11.8 \\
\hline No answer & 3 & 5.9 \\
\hline \multicolumn{3}{|l|}{ Use of sterilisation tests: } \\
\hline Complete tests (chemical+biological) & 5 & 9.8 \\
\hline Only chemical tests & 26 & 51.0 \\
\hline Only biological tests & 1 & 2.0 \\
\hline No tests & 14 & 27.4 \\
\hline No answer & 5 & 9.8 \\
\hline \multicolumn{3}{|l|}{ Results of spore and sterility tests: } \\
\hline Failure rate of spore test in autoclaves $(n=35)$ & 3 & 8.6 \\
\hline Failure rate of spore test in chemiclaves $(n=7)$ & 1 & 14.3 \\
\hline Failure of spore test in ovens $(n=6)$ & 0 & 0 \\
\hline $\begin{array}{l}\text { Sterility test failed for endodontic instruments } \\
\qquad(n=51)\end{array}$ & 4 & 7.8 \\
\hline
\end{tabular}

or disinfection were used by only 29 dentists $(46.8 \%)$, and 20 surgeries $(39.2 \%)$ had dedicated rooms for decontamination, sterilisation, and disinfection.

\section{Sterilisation devices}

The dentists declared that autoclaves were present in $68.6 \%$ of the surgeries, chemiclaves in $13.7 \%$, ovens in $11.8 \%$, and $5.9 \%$ gave no answers (table 2). Periodic checks of autoclaves were usually only carried out with chemical tests (every day), and concurrently with biological tests (one a week) in only five surgeries $(9.8 \%)$. However, no tests were carried out in 14 surgeries $(27.4 \%$, table 2$)$.

\section{Disinfection and preventive procedures}

Disinfection with glutaraldehyde was used in $64 \%$ of the surgeries. Of the dentists $84 \%$ followed disinfection procedures for critical points of dental units, $71 \%$ for taking impressions, 55\% adopted the tray system, and $77 \%$ treated hazardous patients at the end of the working day.

\section{SPORE AND STERILITY TESTS}

Three out of 35 autoclaves $(8.6 \%)$ and one out of seven chemiclaves (14.3\%) failed the spore test (table 2). No failure occurred for the six ovens. Four out of 51 packed and sterilised endodontic instruments $(7.8 \%)$ showed bacterial contamination after incubation in nutrient broth. 
Table 3 Airborne bacterial contamination of dental surgeries $(n=51)$ during dental sessions

\begin{tabular}{lcccc}
\hline & \multicolumn{3}{c}{ Airborne bacterial contamination $\left(c f u / m^{3}\right)$} \\
\cline { 2 - 5 } & Agar plates & Fungi & Blood agar plates * & Staphylococci \\
\hline Positive samples (\%) & 100 & 100 & 100 & 98 \\
Mean & 121 & 62 & 19 & 40 \\
SD & 69 & 51 & 12 & 33 \\
Median & 106 & 49 & 15 & 39 \\
Minimum & 39 & 2 & 1 & 200 \\
Maximum & 350 & 180 & 65 & 3 \\
\hline
\end{tabular}

${ }^{\star}$ Six air samples $(11.8 \%)$ contained group A $\beta$-haemolytic streptococci.

Table 4 Surface bacterial contamination of trolleys $(n=51)$ near dental units

\begin{tabular}{lcccc}
\hline \multicolumn{4}{c}{ Surface bacterial contamination $\left(c f u / 24 \mathrm{~cm}^{2}\right)$} \\
\cline { 2 - 5 } & Agar plates & Fungi & $\begin{array}{l}\text { Staphylococcus } \\
\text { aureus }\end{array}$ & $\begin{array}{l}\beta \text {-haemolytic } \\
\text { streptococci }\end{array}$ \\
\hline Positive samples (\%) & 100.0 & 60.8 & 9.8 & 13.7 \\
Mean & 67 & 12 & 96 & 7 \\
SD & 145 & 20 & 123 & 8 \\
Median & 13 & 4 & 40 & 1 \\
Minimum & 5 & 1 & 8 & 16 \\
Maximum & 630 & 85 & 300 &
\end{tabular}

The mean (SD, range) total bacterial count in air samples was $121(69,39-350) \mathrm{cfu} / \mathrm{m}^{3}$ (table $3)$. The mean (SD, range) total fungi count was $62(51,2-180) \mathrm{cfu} / \mathrm{m}^{3}$, lower than total bacterial counts. Haemolytic Streptococci were found in all the surgeries $19(12,1-65) \mathrm{cfu} / \mathrm{m}^{3}$. Group A Streptococci were found in six surgeries $(11.8 \%) 20(24,1-65) \mathrm{cfu} / \mathrm{m}^{3}$. The count for Staphylococcus species was 40 (33, 3-200) $\mathrm{cfu} / \mathrm{m}^{3}$.

BACTERIAL CONTAMINATION OF SURFACES

The mean (SD, range) total bacterial count on trolley surfaces was 67 (145, 5-630) $\mathrm{cfu} / 24 \mathrm{~cm}^{2}$ (table 4). Fungi were found in $60.8 \%$ of surfaces, but the counts were not usually very high $\left.12(20,1-85) \mathrm{cfu} / 24 \mathrm{~cm}^{2}\right)$. Five trolleys $(9.8 \%)$ were contaminated with Staphylococcus aureus 96 (123, 8-300) and seven (13.7\%) with $\beta$-haemolytic Streptococci 7 $(6,1-16)$.

BACTERIAL CONTAMINATION OF WATER IN DENTAL UNITS

Water samples from hoses showed high bacterial counts at $37^{\circ} \mathrm{C}$ (mean (range) 306 $(1-2200) \mathrm{cfu} / \mathrm{ml})$ and much higher counts at $22^{\circ} \mathrm{C}(2,260(1-102000) \mathrm{cfu} / \mathrm{ml}$, table 5$)$. Very high counts were found in samples from air-water syringes $\left(2619 \mathrm{cfu} / \mathrm{ml}\right.$ at $37^{\circ} \mathrm{C}$ and
$2843 \mathrm{cfu} / \mathrm{ml}$ at $\left.22^{\circ} \mathrm{C}\right)$. Six water samples from hoses $(11.8 \%)$ showed the presence of total coliforms. All the samples were negative for Pseudomonas species, bacteriophages, and $\mathrm{Le}$ gionella species.

Total bacterial counts at $37^{\circ} \mathrm{C}$ were higher than the American Dental Association goal $(<200 \mathrm{cfu} / \mathrm{ml})$ for $47.1 \%$ of hose samples and $56.9 \%$ of air-water syringe samples (table 5). Higher percentages of these water samples (78.4\% and $92.1 \%$ respectively) showed bacterial counts exceeding EU drinking water guidelines $(<10 \mathrm{cfu} / \mathrm{ml})$.

Total bacterial counts at $22^{\circ} \mathrm{C}$ for hose and air-syringe samples exceeded the ADA goal and the EU guidelines in lower percentages.

Twenty dental units $(40.8 \%)$ were provided with a heating system and $42(85.7 \%)$ with an antireflux valve, but no correlation was found between bacterial counts and the presence of these devices.

\section{Discussion}

Some hazardous behaviour was evident among the dental personnel interviewed. A high rate of infection with hepatitis B virus was reported and $30 \%$ of personnel did not receive hepatitis $B$ vaccination (in Italy this vaccine is compulsory only for young people; however, it is strongly recommended for dentists); the correct decontamination procedure for infected instruments was lacking and a low level of knowledge on disinfection mechanisms was evident. Autoclaves were absent in $26 \%$ of dental surgeries and the use of biological controls for testing sterilisation was infrequent. In Italy there are no regulations about dental sterilisation devices and biological tests. Some instruments that had undergone sterilisation were found to be not sterile, probably because of sterilisation failure or faulty storage. A preventive measure as simple and useful as wrapping the critical area with polyethylene film was not commonly adopted (56\% of cases). As in all the Italian dental surgeries glutaraldehyde was often used.

This behaviour is probably due to a lack of information on infective and non-infective health hazards in dental practice in Italy, where dental associations are not yet involved in educational programmes or production of guidelines on this topic.

A comparison with previous surveys on the use of protective devices in different countries

Table 5 Total bacterial counts of water samples obtained from dental unit hoses $(n=51)$ and air/water syringes $(n=51)$

\begin{tabular}{|c|c|c|c|c|}
\hline & \multicolumn{2}{|l|}{ Hoses } & \multicolumn{2}{|l|}{ Air/water syringes } \\
\hline & $\begin{array}{l}\text { Total bacterial counts } \\
\left(\text { cfulml at } 37^{\circ} \mathrm{C}\right)\end{array}$ & $\begin{array}{l}\text { Total bacterial counts } \\
\left(\text { cfulml at } 22^{\circ} \mathrm{C}\right)\end{array}$ & $\begin{array}{l}\text { Total bacterial counts } \\
\text { (cfulml at } 37^{\circ} \mathrm{C} \text { ) }\end{array}$ & $\begin{array}{l}\text { Total bacterial counts } \\
\text { (cfu/ml at } 22^{\circ} \mathrm{C} \text { ) }\end{array}$ \\
\hline Mean & 306 & 2260 & 2619 & 2843 \\
\hline $\mathrm{SD}$ & 460 & 13978 & 13961 & 14964 \\
\hline Median & 110 & 50 & 300 & 200 \\
\hline Minimum & 1 & 1 & 1 & 1 \\
\hline Maximum & 2200 & 102000 & 105000 & 107000 \\
\hline Exceeding ADA goal $(\%)^{\star}$ & $\begin{array}{l}47.1 \\
(n=24)\end{array}$ & $\begin{array}{l}29.4 \\
(n=18)\end{array}$ & $\begin{array}{l}56.9 \\
(n=29)\end{array}$ & $\begin{array}{l}52.9 \\
(n=27)\end{array}$ \\
\hline Exceeding EU guidelines (\%)† & $\begin{array}{l}78.4 \\
(\mathrm{n}=40)\end{array}$ & $\begin{array}{l}43.1 \\
(n=22)\end{array}$ & $\begin{array}{l}92.1 \\
(n=47)\end{array}$ & $\begin{array}{l}60.8 \\
(n=31)\end{array}$ \\
\hline
\end{tabular}

$\star>200 \mathrm{cfu} / \mathrm{ml}$

†EU guidelines for drinking water: $<10 / \mathrm{ml}$ at $37^{\circ} \mathrm{C} ;<100 / \mathrm{ml}$ at $22^{\circ} \mathrm{C}$. 
Table 6 Use of protective devices among dentists in different surveys (\%)

\begin{tabular}{lllll}
\hline Reference & Country & Gloves & Masks & Glasses \\
\hline Grace et al $1989^{38}$ & USA & 87.7 & 63.2 & 82.7 \\
Woo et al $1992^{32}$ & USA & 80 & - & 63 \\
Angelillo et al $1993^{37}$ & Italy & 56.1 & 49.1 & 48.3 \\
Gibson t al $1995^{30}$ & USA & 95 & 83 & - \\
McCarthy et al $1997^{40}$ & Canada & 94 & 79 & 84 \\
McCarthy and MacDonald $1998^{33}$ & Canada & 91.8 & 74.8 & 83.6 \\
Present research & Italy & 94.7 & 94.7 & 90.9 \\
\hline
\end{tabular}

(table 6) shows that gloves were often used, whereas masks were used more often in recent surveys. $^{30} 3233$ 37-39

A previous Italian survey among dentists ${ }^{37}$ showed lower percentages of use of these devices than in our research.

This is the first time that air, surface, and water samples as well as instruments of dental surgeries have been studied concurrently for bacterial contamination. The contamination of air was fairly high; $\beta$-haemolytic Streptococci, Staphylococci, and fungi were often found, producing extensive microbial contamination in the environment. This could be due to the infrequent use of devices for reducing airborne microbial contamination - such as high speed vacuums, dams, or oral disinfectants. Air contamination was also responsible for surface contamination by bacteria, Streptococci, and Staphylococci found in trolleys placed next to dental units.

Data on dental unit water samples showed high levels of microbial contamination. Bacterial counts were much higher than both the American Dental Association target for the quality of dental unit water and the EU drinking water guidelines. Most Italian dentists are probably unaware of this potentially dangerous water pollution, as this is the first time this type of research has been performed in Italy, where guidelines have not yet been prepared by the Italian Dental Association.

On completion of environmental monitoring and submission of questionnaires, we prepared an educational programme for the prevention of infective hazards among dental personnel based on a handbook showing scientifically based procedures to control infection, wall posters on sterilisation, disinfection, and protective procedures to be used in dental surgeries, and seminars to present the results of the research to the personnel involved in the study.

This research has clearly highlighted many critical points in the management of infective hazards among this group of dental personnel and the need to increase knowledge of procedures to control infection and comply with these methods of prevention. Therefore, additional educational programmes at university and after university are needed to improve the quality of dental assistance. The Italian Professional Dental Association, the Italian Hygiene Society, and university teachers should be involved in drawing up guidelines and educational programmes and in performing periodic checks on environmental contamination. As we found in our research, the involvement of dentists in investigations into microbial contamination could be an impor- tant stimulus to promote a more realistic perception of potential microbial risks in the dental surgery.

Increasing awareness of cross infection issues in dentistry among the general public will probably be an additional driving force in changing behaviour of dentists and reducing infective hazards.

1 Merchant VA. Herpesvirus and other micro-organisms of concern in dentistry. Dent Clin North Am 1991;35:283-98. Mori M. Status of viral hepatitis in the world community: its incidence among dentists and other dental personnel. Int incidence among dentist

3 Panis B, Roumeliotou-Karayannis A, Papaevangelou G, et al. Hepatitis B virus infection in dentists and dental students in Greece. Oral Surg Oral Med Oral Pathol 1986;61:343-5.

4 Klein RS, Freeman K, Taylor PE, et al. Occupational risk for hepatitis $\mathrm{C}$ virus infection among New York City dentists. Lancet 1991;338:1539-42.

5 Thomas DL, Gruninger SE, Siew C, et al. Occupational risk of hepatitis $\mathrm{C}$ infections among general dentists and oral surgeons in North America. Am $\mathcal{F}$ Med 1996;100:41-5.

6 Reinthaler F, Mascher F, Stunzner D. Serological examinations for antibodies against Legionella species in dental personnel. F Dent Res 1998;67:942-3.

7 Dersonnel. F Dent Res 1998;67:942-3. miological study of respiratory virus infections among denmiological study of respiratory virus infecto

8 Allsopp J, Basu MK, Browne RM, et al. Survey of the use of personal protective equipment and prevalence of work related symptoms among dental staff. Occup Environ Med 1997;54:125-34.

9 Occupational Safety and Health Administration. Occupational exposure to bloodborne pathogens. Final rule. Title 29, Code of Federal Regulations Part 1910.1030. Federal Regulations 1991;56:64004-182.

10 Udasin IG, Gochfeld M. Implications of the Occupational Safety and Health Administration's bloodborne pathogen standard for the occupational health professional. f Occup Med 1994;36:548-55.

11 Grenier D. Quantitative analysis of bacterial aerosols in two different dental clinic environments. Appl Environ Microbiol 1995;61:3165-8.

12 Legnani P, Checchi L, Pelliccioni GA, et al. Atmospheric contamination during dental procedures. Quintessence International 1994;25:435-9.

13 Osorio R, Toledano M, Liebana J, et al. Environmental microbial contamination. Pilot study in a dental surgery. Int Dent f 1995;45:352-7.

14 King TB, Muzzin KB, Berry CW, et al. The effectiveness of an aerosol reduction device for ultrasonic scalers. $f$ Periodontol 1997;68:45-9.

15 Centers for Disease Control and Prevention. Recommended infection-control practices for dentistry. $M M W R$ Morbid Mortal Wkly Rep 1993;42:1-12.

16 Atlas RM, Williams JF, Huntington MK. Legionella contamination of dental-unit waters. Appl Environ Microbiol 1995;61:1208-13.

17 Pankhurst CL, Philpott-Howard JN. The microbiological quality of water in dental chair units. F Hosp Infect 1993;23:

18 Williams JF, Johnston AM, Johnson B, et al. Microbial contamination of dental unit waterlines. F Am Dent Assoc 1993; 124:59-65.

19 Shearer BG. Biofilm and the dental office. 7 Am Dent Assoc 1996;19:181-9

20 Williams HN, Baer ML, Kelley BS. Contribution of biofilm bacteria to the contamination of the dental unit water supply. F Am Dent Assoc 1995;126:1255-60.

21 Martin MV. The significance of the bacterial contamination of dental unit water systems. Br Dent $\mathcal{F}$ 1987;163:152-4.

22 Piazza M, Guadagnino V, Picciotto L, et al. Contamination by hepatitis B surface antigen in dental surgeries. BMF 1987;295:473-4.

23 Piazza M, Borgia G, Picciotto L, et al. Detection of hepatitis $\mathrm{C}$ virus-RNA by polymerase chain reaction in dental surgeries. $\mathcal{F}$ Med Virol 1995;45:40-2.

24 Centers for Disease Control and Prevention. Possible transmission of human immunodeficiency virus to a patient
during an invasive dental procedure. MMWR Morbid Mortal Wkly Rep 1990;39:489-93.

25 Centers for Disease Control and Prevention. Update: transmission of HIV infection during invasive dental procedures-Florida. MMWR Morbid Mortal Wkly Rep 1991;40:377-81.

26 Bentley EM, Sarll DW. Improvements in cross infection control in general dental practice. Br Dent $\mathcal{F}$ 1995;179:1921

27 DiAngelis AJ, Martens LV, Little JW, et al. Infection control practices of Minnesota dentists: changes during 1 year. $f$ Am Dent Assoc 1989;118:299-303.

28 Gerbert B. AIDS and infection control in dental practices: dentists' attitudes, knowledge, and behavior. $\mathcal{F}$ Am Dent Assoc 1987;114:311-14.

29 Gershon RR, Karkashian C, Vlahov D, et al. Correlates of infection control practices in dentistry. Am $\mathcal{F}$ Infect Control 1998;26:29-34. 
30 Gibson GB, Mathias RG, Epstein JB. Compliance to recommended infection control procedures: changes over six years among Britis
Assoc 1995;61:526-32.

31 Treasure P, Treasure ET. Survey of infection control procedures in New Zealand dental practices. Int Dent $\mathcal{F} 1994 ; 44$ $342-8$.

32 Woo J, Anderson R, Maguire B, et al. Compliance with infection control procedures among California orthodontists. Am $\mathcal{F}$ Orthod Dentofacial Orthop 1992;102:68-75.

33 McCarthy GM, Mac Donald JK. Improved compliance with recommended infection control practices in the dental office between 1994 and 1995. Am F Infect Control 1998;26:24-8.

34 Waddel C. Perception of HIV risk and reported compliance with universal precautions: a compari dental hygienists and dentists. F Dent Hyg 1997;71:17-21.
35 American Public Health Association. Standard methods for the examination of water and wastewater, 19 th $\mathrm{ed}$. Washington: APHA, 1995:8/26-8/32

36 EC Council Directive relating to the quality of water intended for human consumption (80/778/EEC). Official Fournal of the European Community 1980;L229:11-29.

37 Angelillo F, Vollari P, D'Errico M, et al. Dentists and AIDS: a survey of knowledge, attitudes, and behavior in Italy. 7 Public Health Dent 1993;54:145-52.

38 Grace EG, Coehen LA. Attitudes of dentists concerning hepatitis and hepatitis vaccination. Compendium of Continuing Education for Dentists 1989;12:197-200.

39 McCarthy GM, Mamamdras AH, MacDonald JK. Infection control in the orthodontic office in Canada. American 7 Orthod Dentofacial Orthop 1997;112:275-81.

\section{Vancouver style}

All manuscripts submitted to Occup Environ Med should conform to the uniform requirements for manuscripts submitted to biomedical journals (known as the Vancouver style.)

Occup Environ Med, together with many other international biomedical journals, has agreed to accept articles prepared in accordance with the Vancouver style. The style (described in full in the $\mathcal{F} A M A[1]$ ) is intended to standardise requirements for authors, and is the same as in this issue.

References should be numbered consecutively in the order in which they are first mentioned in the text by Arabic numerals on the line in square brackets on each occasion the reference is cited (Manson[1] confirmed other reports[2][3][4][5]). In future references to papers submitted to Occup Environ Med should include: the names of all authors if there are three or less or, if there are more, the first three followed by et al; the title of journal articles or book chapters; the titles of journals abbreviated according to the style of Index Medicus; and the first and final page numbers of the article or chapter. Titles not in Index Medicus should be given in full.

Examples of common forms of references are:

1 International Committee of Medical Journal Editors. Uniform requirements for manuscripts submitted to

2 biomed journals. FAMA 1993;269:2282-6. release into the circulation of histmaine and eosinophil chemotactic factor of anaphylaxis during cold challenge. N Engl f Med 1976;294:687-90.

3 Weinstein L, Swartz MN. Pathogenic properties of invading micro-organisms. In: Sodeman WA Jr, Sodeman WA, ing Pathologic physiolog. Sodechanisms of disease. Philader eds. Pathologic physiology, mechanisms of disease. Philadel-
phia: W B Saunders, 1974:457-72. 